\title{
The Impact of Social Media-Based Marketing on the Turnover of Retailers Based in Polokwane, South Africa
}

\author{
Olabanji. A Oni \\ P.M. Shumba \\ Tafadzwa Matiza \\ Department of Business Management \\ University of Limpopo, Turfloop Campus, South Africa \\ Email: olabanji.oni@ul.ac.za
}

\section{Doi:10.5901/mjss.2014.v5n9p307}

\section{Abstract}

The purpose of this study is to establish the impact of social network-based marketing on the turnover of retailers in the Polokwane area of Limpopo Province South Africa. Primarily the study tests three hypothesis related to digital marketing. The study adopted the quantitative research design, utilising self-complete, likert scale questionnaires to generate the relevant quantitative data. The data from the questionnaires was analysed using frequency diagrams and hypothesis tested by determining averages and standard deviations. Critically, the study found that social media networks as a form of digital marketing had a positive impact on the turnover of retailers in Polokwane. Further-more, it was found that the majority of the retailers who participated in the study utilised social networks in one form or another as a digital marketing tool and viewed it as a viable marketing approach. Ultimately, this paper recommends that retailers who have not integrated social media as part of their integrated marketing communications strategy do so in order to strengthen their online brand presence given the positive impact of digital marketing tools on turnover. More-so as a result of this study, the paper recommends that retailers in Polokwane continue to utilise social networks in their marketing efforts.

Keywords: Social media, digital marketing, retailers, South Africa, turnover

\section{Introduction}

The development of digital media has transformed the practice of marketing communication. Coupled with the explosion in mobile internet access and the relatively convenient availability of smart-phones at low cost, a revolution is in progress as more people than ever before look to use the web to inform their purchasing decisions. This evolution of technology has led to up to 94 per cent of marketing executives indicating that they expect to spend more on social media-based marketing (Busby, Field, Forth, Harsaae, Rose \& Salha, 2010). Not only can businesses now broadcast their offerings to potential customers across the globe, but they have the ability to analyze user interactions with their website, affording an unprecedented understanding of the needs and wants of their audience (Omidvar, Mirabi \& Shorkry, 2011).

Although a considerable amount of research has been conducted on digital marketing, less attention has been paid to the impact of digital marketing on turnover of retailers. The aim of the study is to establish the impact of digital marketing on the turnover of retailers based in Polokwane, South Africa, with the objective to a) investigate the impact digital marketing on turnover of retailers, b) establish the views of retailers in Polokwane with regard to digital marketing as a viable marketing tool and $\mathrm{c}$ ) find out if retailers utilize digital marketing as a marketing tool. With these objectives in mind the study sought to test the following hypothesis:

- $\mathrm{H}_{0}$ : Digital marketing does not increase turnover of retailers

$\mathrm{H}_{1}$ : Digital marketing increases turnover of retailers

- $\mathrm{H}_{0}$ : Retailers do not view digital marketing as a viable marketing tool

$\mathrm{H}_{1}$ : Retailers view digital marketing as a viable marketing tool

- $H_{0}$ : Retailers do not use digital marketing

$H_{1}$ : Retailers use digital marketing

The significance of this study is that it investigates the impact of digital marketing on the turnover of retailers based in Polokwane, South Africa, while endeavouring to discover the views of retailers towards digital marketing as a viable 
marketing tool, find out how and if retailers utilise digital marketing and ultimately provide recommendations to retailers on digital marketing.

\section{Review of Related Literature}

Traditional marketing practice includes advertising tools such as print advertisements in magazines and newspapers, posters, radio, television commercials, brochures and billboards. Digital Marketing in relation to retail commerce involves attracting customers to the companies' websites and retaining them for repeat patronage. As the number of internet users approaches $50 \%$ of the South African adult population, those who fail to engage online are likely to fail to build or even maintain their brands (de Lanerolle, 2012). Although a considerable amount of research has been conducted on digital marketing, less attention has been paid to the impact of digital marketing on turnover of retailers. For instance, Johnson's (2013) study focuses on using social network marketing to strengthen brands and communicate with customers, while Bernariusz's (2013) focuses on the need for companies to stay flexible in the face of constant change and embrace digital as a cornerstone of their marketing strategies, to increase online markets. Similarly, a study by de Lanerolle (2012) focused on the risks associated with retailers failing to engage customers online, concluding that no-compliant retailers would be more likely to fail to build or even maintain their brands effectively.

In practice, many brands have established a social media presence with the best of intentions, to get to know their customers and engage with the online community. Brands such as Coca-Cola have an active Facebook base of over 32 million fans, who interact not only with the brand based on information it supplies but provide their own user-generated content (UGC) in the form of comments, photos, and videos, thus interacting with each other and growing the brand organically (Atanassova, 2011). According to Bernariusz (2013), companies need to stay flexible in the face of constant change, and embrace digital marketing as a cornerstone of their marketing strategies. Digital marketing is now a proven part of the marketing mix. To this end, Du Plessis, Strydom and Jooste (2012), outline two digital marketing options available to retailers; Pull and Push Digital marketing:

- Pull digital marketing - requires the customer to seek out and specifically select (pull) the content. Examples include websites, blogs and streaming media (audio and video), all of which have a specific link (Unique Resource Locator) that users have to access to view the content

- Push digital marketing - involves both the creator of the message (marketer) and the user (recipient of the message). Examples include e-mail and SMS where the marketer has to send the message (push) to the user in order for it to be received.

Smith (2012) believes that, Companies should connect with this new generation of consumers on their turf, the digital arena; this will facilitate successful communications. Marketing via the internet can level the playing field between large and small companies.

\subsection{Social Networks and Media}

Social networks involve a group of people with shared social interaction and common ties (Laudon \& Traver, 2012). Weber and Wales (2009) describe social networks as; places where people with a common interest or concern come together to meet people with similar interest, express themselves and vent. The most widely used social networks include Facebook, MySpace, Linkedln, and many more. The introduction of "Web 2.0", which is characterised by user generated content and interactive social media, for example, allows public users to co-develop and exchange content on the internet via blogging, tagging, wikis, and media sharing, and to network socially in novel ways via the proliferation of social networking sites, such as, Facebook, YouTube and Twitter (Baker, 2011). In 2004, Facebook introduced social networking to the masses, while in 2006 Twitter launched and made social networking instant and mobile (Baker, 2011).

It is evident that social networks have become a vital marketing channel for reaching potential customers and changed the way in which people learn about and ultimately choose products and services (Phelan, Chen \& Haney, 2013). Additionally, research has identified interactions between the firm and consumer via social media aids in strengthening customer loyalty and improving overall satisfaction (Kasavana, Nusair \& Teodosic, 2010, Xiang \& Gretzel, 2010). In addition to social networks, online review sites are widely available, allowing consumer generated content, such as product reviews, suggestions and complaints to circulate at an incredible rate to an immense online audience (Xiang \& Gretzek, 2010). According to Phelan et al (2013), marketers have noticed that customers' feedback regarding product/service consumption on social networks can reveal variable marketing messages. As such, the trend of strategic marketing is moving toward understanding customer demand and managing customer engagement via social networks.

Social network-based marketing (using online social networks to build and strengthen brands), is one of the fastest 
growing forms of marketing. Marketers cannot ignore the vast audience that social networks such as Facebook, Twitter, and Linkedln are gathering, rivaling television and radio in size and reach (Laudon \& Traver, 2012). While e-mail remains the Web's most popular activity, one may suggest that it is about to be eclipsed by social networks. Increased engagement with customers helps an organisation in its new product development programmes, customer relationship marketing and maintenance of lifetime value. However, as Chikandiwa, Contogiannis and Jembere (2013) suggest, to float in effectively social media-based marketing demands marketers to be creative, develop disciplined processes and constantly improve their strategies. Over $80 \%$ of U.S. businesses now have Facebook pages and a presence on many other social network sites.

Social media help build brand awareness, visibility, reputation, knowledge sharing, customer acquisition and retention, low cost promotions, new product development, customer relationship marketing (Kaplan \& Haenlein, 2010, Bolotaeva \& Cata, 2010). As a business model, social media tools bring opportunities to the advertising industry by virtue of it being free and easily accessible. It also has great potential for generating multi-revenues and market research in the content of ethnography (Ahlqvist, Back, Heinonen \& Halonen, 2008, Sarkkinen, 2009). According to Weber (2009:25-26), the social network 'web' provides numerous opportunities for strengthening and expanding relationships with all your customers. These opportunities include:

- Targeted brand building. Depending on the size and breath of a company's customer base, communities can be organised by vertical market (e.g., high tech, energy, consumer packed goods, retail, automotive) or by horizontal topics that cut across multiple sectors (e.g., finance, manufacturing, the environment).

- Lead generation. At launch time, you can introduce the new product or service both in the online and offline worlds. Using the Social web, you can reach more people-- and reach highly targeted markets-- more quickly and more cost-effectively than through traditional broadcast and print media.

- Partnerships. In addition to customers and prospects, the social web is a great tool for staying connected with distributors, technology vendors, manufacturers, and other business partners. Often companies announce these partnerships with great fanfare but they fade away over time because it requires a significant effort to maintain them. Social networking can help your company's; distributors, store managers, sales representatives, and others stay in touch and consult with one another. A community (Social network community) is a flexible platform for your partners to receive the latest company updates, news from the head office, and stories from the field.

- Research and Development. Isolation is the greatest obstacle to product and service innovation. Conversely, collaboration stimulates new ideas and new approaches that can lead to breakthrough solutions to complex problems. Social networks can bring product developers together in real time. As GlaxoSmithKline learned, by including customers in the product development process, companies can forge bonds that foster long-term product or brand loyalty.

- Employee communications. The social networks also afford numerous opportunities to strengthen and expand employee communications.

\section{Methodology}

This study was conducted as a quantitative enquiry and utilised traditional quantitative research tools which are systematic and structured, and aimed at a direct, open manner of obtaining information. Research quantitative research design relates directly to the testing of the hypothesis and as Bless, Smith and Kagee (2011) suggest, it results in a specification of the most adequate operations to be performed in order to test the hypothesis.

\subsection{Population and Sample}

This study focused on retailers in the Polokwane area of Limpopo Province, South Africa. The universal population for this study was 110 retail shops registered with a Limpopo provincial government department as retailers. These retailers represented businesses in the clothing, furniture, food, telecommunications, motor vehicle, stationary and office machinery sectors. The researcher decided to include all registered retailers in the study hence no sampling was employed. However, due to the quantitative nature of the study even though all retailers in the Polokwane were sampled, in-order to establish a truly representative result from the sample frame of retailers we established that from the sample frame of $N=110$. From a population of $N=110$ at $95 \%$ confidence level it was established by an online random sample calculator that the study needed at least 93 questionnaires returned by respondents at $4 \%$ error to be valid (Custom 
Insight, 2013).

\subsection{Data collection and analysis}

This study collected data using self-complete structured questionnaires containing structured questions, which, according to Zikmund, Babin, Carr and Griffin (2013) limits the number of allowable responses. The questionnaire was constructed to test the hypothesis concerning retailers' frequent use of Social Networks to meet their marketing objective of increasing turnover rate. It was also used to determine their attitude towards Digital marketing as a viable marketing tool and their views regarding Social Network Marketing (SNM) as a rapidly growing marketing tool and how often they use it. The bulk of the questionnaire comprised of five constructs; Demographical information, Social Network Marketing, Digital Marketing, Turnover rate and Social Networks.

Items measuring each construct are derived from related research in the marketing and internet literature. The strategy of the frequent usage of Social Networks to market their business is rated on a five-point Likert scale ranging from $1=$ None to $5=$ Frequently. Their behaviour towards Digital marketing being a viable marketing tool was rated on a five-point Likert scale ranging from 1= Strongly Disagree to $5=$ Strongly Agree. Their attitude towards Social Network Marketing being a rapidly developing marketing tool was rated on a five-point Likert scale ranging from $1=$ Strongly Disagree to $5=$ Strongly Agree. The impact this marketing strategy of using Social Networks had on their turnover was rated on a five-point Likert scale ranging from $1=$ Decreased a lot to $5=$ Increased a lot. On five most popular and frequently used social networks in South Africa, they were each rated on the scales of 1= Don't know it to 3= Use it. Other Digital tools which were not included in the questionnaire individually but were clustered together refer to; YouTube, Blogs, Tumblr, Instagram, MySpace, respectively.

The study utilised structured questionnaires to collect data, and the questions asked in the questionnaire were closed or pre-coded; to offer respondents a range of answers to choose from (Welman, Kruger \& Mitchell, 2005). The data from the questionnaires was analysed using frequency diagrams and hypothesis tested by determining averages and standard deviations. Data analysis was conducted to detect consistent patterns within the data, such as the consistent co-variance of two or more variables (Bless, Higson-Smith \& Kagee, 2011).

\section{Results}

The response rate of the management was $88.2 \%$. The findings were interpreted using statistical tests, tables and graphs. The descriptive statistics was also used to determine the mean and standard deviation of the results. Total number of participants was $N=97$ made up of 56 male and 41 female respondents.

Table 1: Age of Respondent * Gender of Respondent Cross tabulation

\begin{tabular}{|l|c|c|c|}
\hline \multirow{2}{*}{ Age of respondent } & \multicolumn{2}{|c|}{ Gender of Respondent } & \multirow{2}{*}{ Total } \\
\cline { 2 - 3 } & Male & Female & \\
\hline Between 20-25 & 7 & 3 & 10 \\
Between 26-25 & 12 & 16 & 28 \\
Between 36-45 & 24 & 9 & 33 \\
Between 46-55 & 8 & 8 & 16 \\
$>55$ & 5 & 5 & 10 \\
Total & 56 & 41 & 97 \\
\hline
\end{tabular}

Source: Research Data

\subsection{Use of Digital Marketing}

By using the $X^{2}$ test for equality of proportions when there are more than two. In tabulating the responses to the single question, "My business uses Digital Marketing". The table represents the responses to the question concerning whether retailers choose to use digital marketing. The table below shows that $55.7 \%$ of the 97 respondents use digital marketing in their business and only $44.3 \%$ don't. Thus shows that more than half of the respondents have confidence in adopting the strategy of using digital marketing in their business. 
Table 2: Frequent use of digital marketing

\begin{tabular}{|ll|c|c|c|c|}
\hline & Frequency & Percent & Valid Percent & Cumulative Percent \\
\hline \multirow{2}{*}{ Valid } & No & 43 & 44.3 & 44.3 & 44.3 \\
& Yes & 54 & 55.7 & 55.7 & 100.0 \\
& Total & 97 & 100.0 & 100.0 & \\
\hline
\end{tabular}

\section{Source: Research Data}

The figure 1 below shows the use of digital marketing per store category, respectively. According to the data presented, stores in the "Other" category are the highest category that don't use digital marketing, with $16(10+1+5)$ stores out of the population of 97 stores surveyed, which yields $16.5 \%$, followed by clothing at $14.4 \%$.

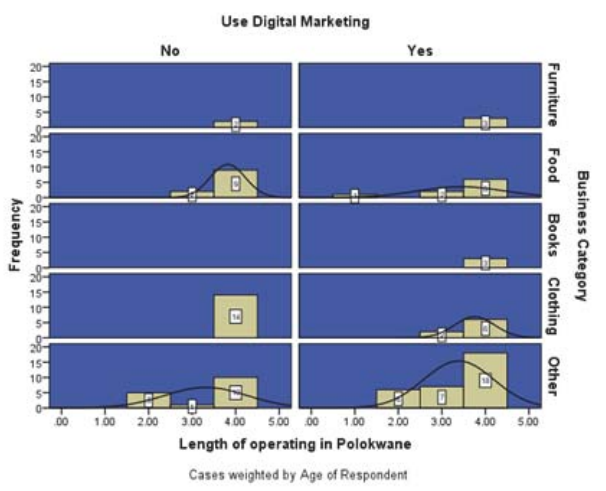

Figure 1: Use of digital marketing

Source: Research Data

The category that scored highest in the use of digital marketing are the stores in the "Other" category (Other represents stores that fall under telecommunications, motor vehicle, general dealers, and wholesalers). With 31 stores out of the population of the population of 97 surveyed, yielding $32 \%$.

\subsection{Frequent use of social network marketing}

Table 3 below presents the data collected for the frequent use of social networks to market their business by respondents. With the data presented, it shows that $38.1 \%$ of respondents frequently make use of social network marketing in their business, whilst only $10.3 \%$ don't. Safe to assume that a total of 87 stores surveyed, i.e. $89.7 \%$ do make use of social networks to market their business either; rarely, sometimes, often and frequently, respectively (Figure 2) below:

Table 3: Use of Social Media

\begin{tabular}{|l|c|c|c|c|}
\hline & Frequency & Percent & Valid Percent & Cumulative Percent \\
\hline None & 10 & 10.3 & 10.3 & 10.3 \\
Rarely & 2 & 2.1 & 2.1 & 12.4 \\
Valid Sometimes & 15 & 15.5 & 15.5 & 27.8 \\
Often & 33 & 34.0 & 34.0 & 61.9 \\
Frequently & 37 & 38.1 & 38.1 & 100.0 \\
Total & 97 & 100.0 & 100.0 & \\
\hline
\end{tabular}

Source: Research Data 


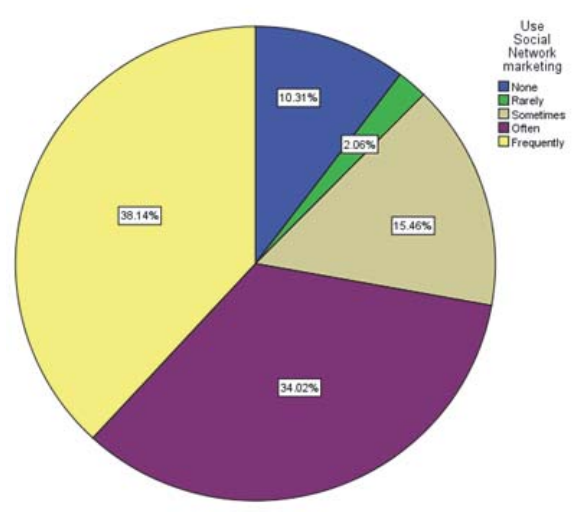

Figure 2: Utilisation of social media

Source: Research Data

Figure 3 below represent the frequent use of social network marketing by respondents per job designation, respectively. According to the chart, General Managers adopt the strategy of using social networks to market their businesses, followed by marketing and sales managers. This shows that store/shop executives have confidence in the use of social networks to market their businesses.

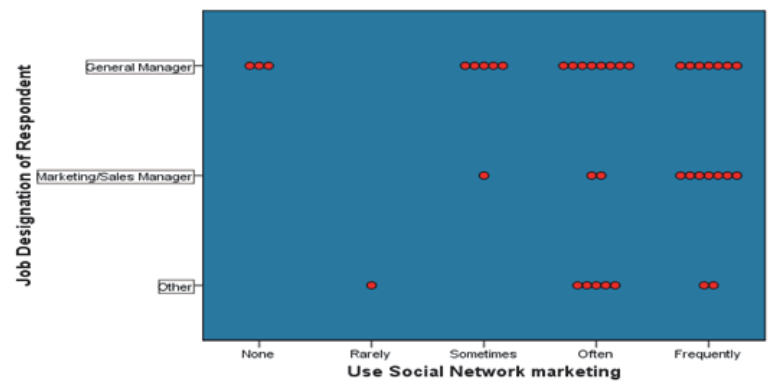

Figure 3: Utilisation of social media in relation to job designation

Source: Research Data

\subsection{Views digital marketing as a viable marketing tool}

Table 4 below presents the views and attitudes of respondents towards digital marketing as a viable marketing tool. According to the data collected and presented, $9.3 \%$ out of the population of 97 respondents surveyed disagreed, whilst $34 \%$ agreed and $48.5 \%$ strongly agreed. Safe to assume, $82.5 \%(34+48.5)$ of the respondents positively view digital marketing as a viable marketing tool. Leaving $8.2 \%$ of the respondents surveyed unsure.

Table 4: Digital marketing as a viable marketing tool

\begin{tabular}{|c|c|c|c|c|c|}
\hline & & Frequency & Percent & Valid Percent & Cumulative Percent \\
\hline \multirow{6}{*}{ Valid } & \multirow{2}{*}{$\begin{array}{l}\text { Strongly Disagree } \\
\text { Disagree }\end{array}$} & 0 & 0 & 0 & 0 \\
\hline & & 9 & 93 & 93 & 93 \\
\hline & Not sure & 8 & 8.2 & 8.2 & 17.5 \\
\hline & Agree & 33 & 34.0 & 34.0 & 51.5 \\
\hline & Strongly Agree & 47 & 48.5 & 48.5 & 100.0 \\
\hline & Total & 97 & 100.0 & 100.0 & \\
\hline
\end{tabular}

Source: Research Data 


\subsection{Impact of digital marketing on the turnover rate}

Table 4.5.1.5 (a) below shows that $56.7 \%$ of the respondents say that after using digital marketing in their business, their turnover rate Increased a little more. However, $25.8 \%$ of the responded argue that their turnover rate never changed at all after marketing digitally. But, $17.5 \%$ of the responded say their turnover increased a lot after using digital marketing. This means that $74.2 \%(56.7+17.5)$ of the respondents confirm that the use of digital marketing has a positive impact on turnover.

Table 5: Impact on Turnover

\begin{tabular}{|l|c|c|c|c|}
\hline & Frequency & Percent & Valid Percent & Cumulative Percent \\
\hline Decreased a lot & 0 & 0 & 0 & 0 \\
No change at all & 25 & 25.8 & 25.8 & 25.8 \\
Valid Increased a little more & 55 & 56.7 & 56.7 & 82.5 \\
Increased a lot & 17 & 17.5 & 17.5 & 100.0 \\
Total & 97 & 100.0 & 100.0 & \\
\hline
\end{tabular}

Source: Research Data

According to Figure 4 below for stores that have been operating in Polokwane less than a year ago, digital marketing helped increase their turnover rate. This goes to show that digital marketing is also useful for businesses which are new to an area. The data presented suggests that for businesses that have been operating in the Polokwane area for more than five years, both male and female respondents seem to agree that digital marketing has positively impacted their turnover rate. About $25(23+2)$ male store executives for businesses that have been operating in Polokwane for more than five years say that the use of digital marketing has helped increase their turnover rate, while $23(18+5)$ female store executives of the same sample agree. That is $48(25+23)$ out of $71(48+14+9+0)$ which equals $67.6 \%$ respondents whose businesses have been operating in Polokwane for more than five years confirm that the adoption has positively impacted their turnover rate.

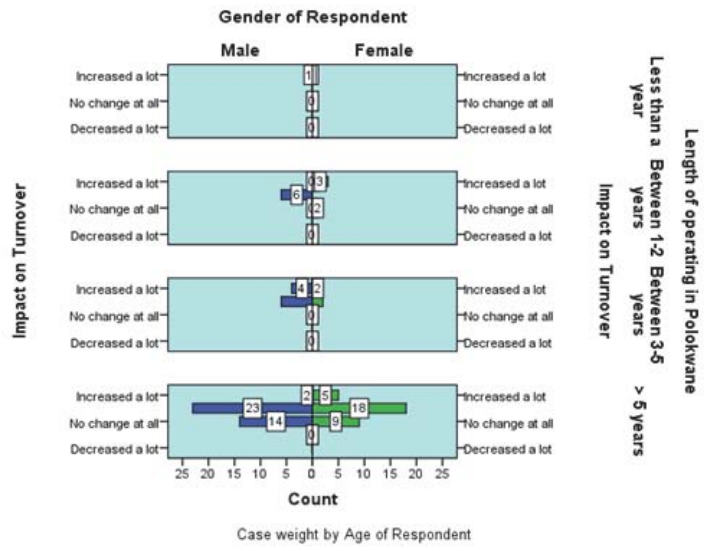

Figure 4: DM impact on turnover in relation to age and duration of operations Source: Research Data

The frequency of using social network marketing does also have an impact on turnover rate (see Figure 5). According to the data presented, stores that fall under the category "Other", make frequent use of social network marketing than any other category, which is why they experience a more positive impact on their turnover rate than any other category. According to the figure, shops that use social network marketing 'often' experience a positive impact on their turnover rate as this increases it a little bit more. Also shops that use it frequently follow suit. In comparison, shops that don't use social network marketing reported a negative impact on their turnover rate. This could be because they are losing customers to competitors who adapted to using social network marketing to market their businesses. 


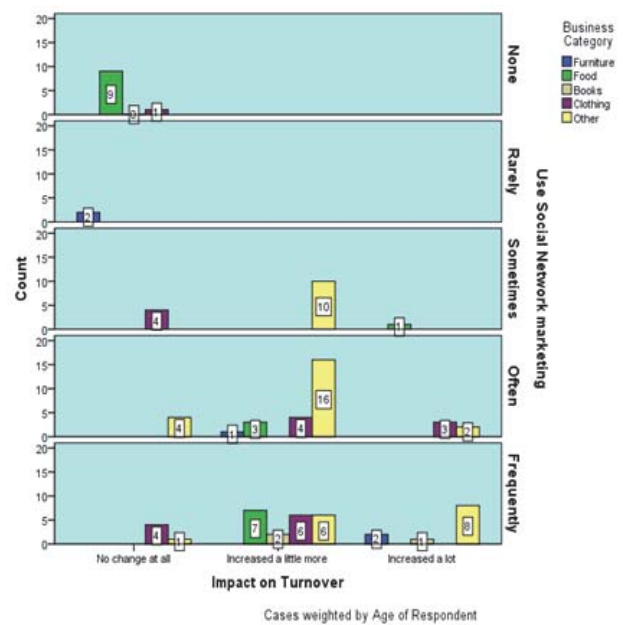

Figure 5: Frequency of Social Network utilisation versus impact on turnover

Source: Research Data

For a more statistical representation of the results of the frequent use of social network marketing and the impact that has on the turnover rate. Figure 6 indicates that shops who rarely and not at all use social network marketing, their turnover rate remains stagnant. But for shops that use social network marketing Sometimes:

- $26.67 \%$ say no change at all

- $66.67 \%$ say increased a little bit more

- $6.67 \%$ say increased a lot

While those who use it often:

- $12.12 \%$ say no change at all

- $72.73 \%$ say increased a little bit more

- $15.15 \%$ say increased a lot

And those who use it frequently:

- $13.51 \%$ say no change at all

- $56.76 \%$ say increased a little bit more

- $29.73 \%$ say increased a lot

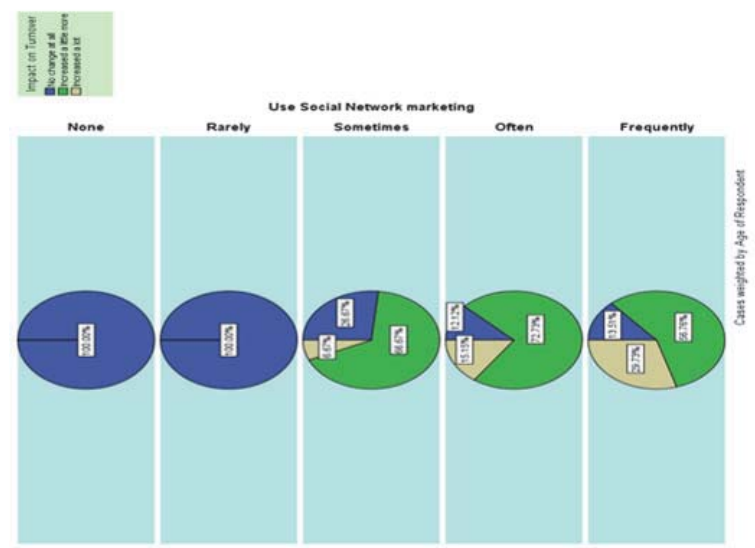

Figure 6: Use of social network marketing

Source: Research Data 
Figure 7 shows the impact digital marketing has on the shops/stores' turnover per category, respectively. The category with the highest negative impact on turnover is food at $45 \%$, followed by clothing at $40.91 \%$, then furniture at $40 \%$ and lastly other at $10.63 \%$. The category with the highest positive impact of increasing a little bit more is other at $68.09 \%$, followed by books at 66.67 , then food at $50 \%$ then clothing at $45.45 \%$ and lastly furniture at $20 \%$. Shops in the books category seem to be the ones that benefit more from using digital marketing as compared to other categories with a $100 \%(33.33+66.67)$ positive impact on turnover.

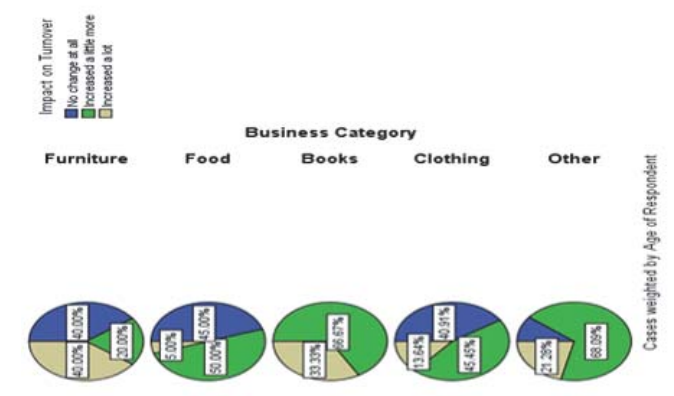

Figure 7: Impact on turnover by category

Source: Research Data

\section{Conclusions and Recommendations}

Phelan et al (2013) suggest that social networking as a marketing technique is still relatively a new phenomenon. The aim of this research was to determine whether digital marketing through social networks positively/negatively impacts the turnover rate. Results from the statistical test taken, Chi-square test show that the objectives of the study were fairly met and in testing the hypotheses: Digital marketing does not increase turnover of retailers; we have concluded that we are going to reject the null hypotheses because per test results, it has been proven that digital marketing does indeed impact turnover in a positive way. Most retailers in the Polokwane area have adapted to using digital marketing to further strengthen their brands, reach out to customers and ultimately increase their turnover.

The results from the study suggest that digital marketing is a viable marketing tool. Findings suggest that frequent use of social network marketing has a positive impact on turnover of retailers. Data analysis revealed that a lot of retailers are familiar with Facebook and Twitter but there several shortcomings managers appear to have in using Linkedln, BBM, and Mxit. This could be because they aren't as much popular as their competitors: Facebook and Twitter. Creating an online presence through the use of social networks is every business' first step towards harnessing the power of social media. The viral spread of positive feedback via social network marketing is based upon constant interactions between the practitioner and customers.

Based on the results of this study we conclude the following:

- $\mathrm{H}_{0}$ : Digital marketing does not increase turnover of retailers

$\mathrm{H}_{1}$ : Digital marketing increases turnover of retailers

Result- We Reject $\mathrm{H}_{0}$ and Accept $\mathrm{H}_{1}$

- $\mathrm{H}_{0}$ : Retailers do not view digital marketing as a viable marketing tool

$\mathrm{H}_{1}$ : Retailers view digital marketing as a viable marketing tool

Result- Reject $\mathrm{H}_{0}$ and Accept $\mathrm{H}_{1}$

- $\mathrm{H}_{0}$ : Retailers do not use digital marketing

$H_{1}$ : Retailers use digital marketing

Result- We Reject $\mathrm{H}_{0}$ and Accept $\mathrm{H}_{1}$

According to the overall results of the study it is recommended that retailers should concentrate more on the frequent use on social networks to market their businesses. In terms of digital marketing being a viable marketing tool, they should consider including it in their marketing efforts as one of the integrated marketing communication component. 
This will help retailers to strengthen their online presence and effectively communicate with their customers. It is also recommended that they look into using social network marketing for consumer relationship management. Constantly communicating with customers will not only strengthen and maintain their relationship but will also help retain customers. Retailers should also integrate their strategy of digital marketing with traditional marketing strategies. Further studies could look into the importance of digital marketing for consumer relationship management which includes: customer retention, customer satisfaction and acquiring new customers. Furthermore other studies can examine the importance of monitoring and controlling social network marketing for businesses and this is applicable even in different industries, including risk from new technologies, system interactions, unforeseen and the dynamic social networking environment.

\section{References}

Ahlqvist, T. Back, A. Heinonen, S \& Halonen, M. (2008). Social media roadmaps: exploring the future triggered by social media. Espoo 2008. VTT Tiedotteita - Research Notes 2454, 78p.+ app. 1 p.

Atanassova, R. (2011). Brands on social media: adding value or not. [Online] Available: http://www.bizcommunity.com/Article/196/82 162186.html (Accessed: August 30, 2013).

Baker, S.A. (2011). From the criminal crowd to the "mediated crowd": the impact of social media on the 2011 English riots. Safer Communities. 11(1), pp.40-49.

Bernariusz, A. (2013), Digital advertising reaches critical mass in SA. [Online] Available: http://www.bizcommunity.com/Article/196 116/99039.html\#topstory (Accessed October 30, 2013).

Bless, C. Higson-Smith, C \& Kagee, A. (2006). Fundamentals of social research methods: An African perspective, $4^{\text {th }}$ Edition. Cape Town: Juta and Co. Ltd.

Bolotaeva, V. \& Cata, T. (2010). Marketing opportunity with social network. Journal of Internet Social Networking and Virtual communities.

Busby, E. Field, P. Forth, P. Harsaae, J. Rose, J \& Salha, H. (2010).The CMO's Imperative: Tackling new Digital Realities. Boston Consulting Group. [Online] Available: www.bcg.com/documents/file66995.pdf (Accessed July 13, 2013).

Chikandiwa, S.T. Contogiannis, E. \& Jembere, E. (2013).The adoption of Social Media Marketing in South African Banks. European Business Review, 25(4), pp. 365-381.

Custom Insight (2013). Random sample calculator. [Online] Available: www.custominsight/article/random-sample-calculator.asp. (Accessed July 13, 2013).

de Lanerolle, Indra. (2012), The new age. [Online] Available: http://www.worldinternetproject.net. (Accessed October 30, 2013).

Du Plessis P.J, Strydom J.W \& Jooste C.J (2012). Marketing Management.6th Edition. Cape Town: Juta and Co. Ltd.

Johnson, A. (2013). Digital marketing 2013. Lessons from the past. [Online] Available: http://www.bizcommunity.com/Article.aspx?1 $=196 \& c=423 \& i=88089$ (Accessed October 30, 2103).

Kaplan, A.M. \& Haenlein, M. (2010).Users of the world, Unite! The challenges and opportunities of social Media. Business Horizons, 53(1),pp. 59-68

Kasavana, M.L. Nusair, K. \& Teodosic, K. (2010), Online social networking: redefining the human web. Journal of Hospitality and Tourism Technology, 1(1), pp. 68-82.

Laudon, K.C. \& Traver, C.G. (2012). E-commerce 2012: Business, Technology, Society. $8^{\text {th }}$ Edition. Essex: Pearson Education Limited.

Omdivar, M.A. Mirabi, V.R. \& Shorky, N. (2011). Analysing the Impact of Visitors on Page Views with Google Analytics. International Journal of Web and Semantic Technology (IJWesT), 2(1), pp. 14-32.

Phelan, K.V. Chen, H.T. Haney, M. (2013)." "Like" and "Check -in": How hotels utilize Facebook as an effective marketing tool. Journal of hospitality and Tourism Technology, 4(2), pp. 134-154.

Sarkkinen, H. (2009). The role of social media in customer communication in business-to-business markets. Master Thesis. Department of Marketing. University of Oulu, Oulu.

Smith K.T. (2012).Longitudinal study of digital marketing strategies targeting Millennials. Journal of Consumer Marketing. 29 (2), pp 8692.

Weber, I. \& Wales, J. (2009). Marketing to the social web: Now covers measuring social media. $4^{\text {th }}$ Edition. New Jersey: John Wiley and Sons Inc.

Xiang, Z. \& Gretzel, U. (2010), Role of social media in online travel information search. Tourism Management, 31(2), pp. 179-188.

Zikmund W, Babin B, Carr J \& Griffin M (2013). Business Research Methods.9th Edition. Canada: Nelson Education Ltd. 